\title{
Caloric restriction in obese pre-diabetic rats prevents beta-cell depletion, loss of beta-cell GLUT 2 and glucose incompetence
}

\author{
M. Ohneda ${ }^{1}$, L.R.Inman ${ }^{1,2}$, R.H. Unger ${ }^{1,2}$ \\ ${ }^{1}$ Center for Diabetes Research and Gifford Laboratories, Departments of Internal Medicine and Pathology, University of Texas \\ Southwestern Medical Center, Dallas, Texas USA \\ ${ }^{2}$ Department of Veterans Affairs Medical Center, Dallas, Texas, USA
}

Summary Pre-diabetic male Zucker diabetic fatty rats (ZDF) become diabetic between 8 and 10 weeks of age. At that time their beta cells exhibit high basal insulin secretion, absent insulin response to glucose and loss of GLUT 2 glucose transporter. Beta-cell volume, which is increased at the onset of non-insulin-dependent diabetes, declines precipitously by age 18 weeks. To determine if expression of this diabetic phenotype was dependent upon the increased food intake of these rats, they were diet-matched to lean littermates for 12 weeks beginning at 6 weeks of age. Untreated control ZDF rats received an unrestricted diet for 3 months. All of the controls became hyperglycaemic by 8 weeks of age, whereas all diet-matched rats remained euglycaemic throughout the 3 months, despite the fact that at 18 weeks of age their mean body weight equaled that of obese rats on an unrestricted diet. In the former rats glucosestimulated insulin secretion was absent at 12 weeks of age and GLUT-2-positive beta cells had fallen below $30 \%$. The volume fraction of their beta cells was
2.6 times normal at this age but by 18 weeks of age it had declined by $75 \%$. Diet restriction for 3 months prevented the loss of glucose-stimulated insulin secretion and the reduction of beta-cell GLUT-2 and beta-cell volume fraction. However, neither the elevated basal insulin secretion nor the exaggerated arginine-stimulated insulin secretion of the obese rats was reversed or prevented by caloric restriction. We conclude that in diabetic ZDF rats the glucose incompetence of beta cells and the reduction of betacell GLUT 2, which coincide with the onset of hyperglycaemia, and the subsequent loss of beta-cell volume, occur only when the caloric intake is excessive. The increased basal insulin secretion and exaggerated insulin response to arginine appear to be relatively independent of caloric intake. [Diabetologia (1995) 38: 173-179]

Key words GLUT 2, Zucker rats, caloric restriction, beta-cell depletion.
The beneficial effect of dietary restriction and weight reduction on the hyperglycaemia of patients with obesity-associated non-insulin-dependent diabetes mellitus (NIDDM) has been appreciated for over

Received: 10 May 1994 and in final revised form: 5 September 1994

Corresponding author: Dr. R. Unger, Center for Diabetes Research, University of Texas Southwestern Medical Center, 5323 Harry Hines Boulevard, Dallas, Texas 75235, USA Abbreviations: NIDDM, Non-insulin-dependent diabetes mellitus; ZDF, Zucker diabetic fatty rats; GSIS, glucose-stimulated insulin secretion; GLUT-2, glucose transporter.
50 years [1]. Although there is evidence that this benefit may in part be due to improved beta-cell function $[2,3]$, islets of diabetic patients are not available for study. We have therefore examined the effects of caloric restriction on both the function and the morphology of beta cells in Zucker diabetic fatty (ZDF) rats, a rodent model of diabetes that resembles human NIDDM [4]. In this model, as in human NIDDM [5], hyperglycaemia is associated with a loss of glucose-stimulated insulin secretion (GSIS) [6]. Concomitantly, there is a decline in the percent of beta cells displaying the high $\mathrm{K}_{\mathrm{m}}$ glucose transporter GLUT 2 which is correlated with the loss of GSIS and with the hyperglycaemia [7, 8]. Additionally, 
there is a subsequent reduction in the volume fraction of the beta cells [7].

We report here that a $50 \%$ reduction in caloric intake completely prevents not only the hyperglycaemia, but also all three of the foregoing components of the beta-cell phenotype in NIDDM: the loss of GSIS, the reduction in the percent of GLUT-2-positive beta cells and the decline in the volume fraction of beta cells.

\section{Materials and methods}

Animals. Zucker diabetic fatty rats [ZDF/Drt-fa (F10)], obtained in 1991 from Dr. R.Peterson (University of Indiana, Ind., USA) and inbred in our animal facility, were used in these studies, beginning at 6 weeks of age. In this colony obese male ZDF rats (fa/fa) uniformly develop hyperinsulinaemia by 6 weeks of age and become hyperglycaemic between 8 and 10 weeks of age. Obese female ZDF rats (fa/fa) develop comparable increases in basal insulin secretion but do not develop diabetes.

Animals were kept in individual cages and their food intake, urine volume, and glycosuria were monitored daily. Body weight and postprandial plasma glucose $(09.00$ hours, Beckman Glucose Analyzer II, Brea, Calif., USA) were measured weekly in tail vein blood. Plasma insulin levels were not measured because of the limited availability of blood, the variable haemolysis and hyperlipidaemia and the fact that pancreatic perfusion data in a controlled extracellular environment was considered to be more reflective of steady-state beta-cell function than a single plasma insulin determination. All animals received standard rat chow given between 12.00 14.00 hours. Some were fed ad libitum while others were "diet-matched" to a lean littermate; i.e., they were given the same quantity of food consumed by a lean littermate on the previous day, which averaged $19 \pm 0.3 \mathrm{~g} /$ day at 6 weeks, $23 \pm 0.7 \mathrm{~g} /$ day at 12 weeks and $22 \pm 0.5 \mathrm{~g} /$ day at 18 weeks of age. Otherwise obese rats consumed from $28 \pm 0.5 \mathrm{~g} /$ day of chow at 6 weeks, $46 \pm 1.5 \mathrm{~g} /$ day at 12 weeks and $47 \pm 0.3 \mathrm{~g} /$ day at 18 weeks when given free access to food. Standard rat chow contained $24.8 \%$ protein, $48.3 \%$ carbohydrate, $6.5 \%$ fat (gross energy $4.05 \mathrm{kCal} / \mathrm{g}$, Teklad F6 8664, Harlan Teklad, Madison, Wis., USA). All rats had free access to water.

The obese rats fed all day and night on the unrestricted diet, whereas all food was consumed within $3 \mathrm{~h}$ when their food intake was restricted.

Animals were killed at 6 weeks of age (1-3 weeks before the onset of diabetes), at 12 weeks of age (2-5 weeks after onset) and at 18 weeks ( $8-11$ weeks after onset).

Beta-cell function. At the end of the experimental periods pancreases were perfused by the method of Grodsky and Fanska [9] as previously modified [10]. Our standard perfusate consisted of Krebs-Ringer bicarbonate buffer ( $\mathrm{pH} 7.6$ ) containing $5.6 \mathrm{mmol} / 1$ glucose and $5 \mathrm{mmol} / \mathrm{l}$ of pyruvate, fumarate and glutamate. After a 10-min baseline period during which only the standard perfusate was given, $20 \mathrm{mmol} / 1$ glucose was coperfused via a sidearm catheter for $10 \mathrm{~min}$. This was followed by a 5-min "rest interval" during which only the standard perfusate was perfused. Then $10 \mathrm{mmol} / \mathrm{l}$ arginine was co-perfused for $10 \mathrm{~min}$. Samples were collected at 1 -min intervals. Flow rate was maintained at $2.7 \mathrm{ml} / \mathrm{min}$. Samples were stored at $-20^{\circ} \mathrm{C}$ until assay for insulin by the Herbert modification [11] of the method of Yalow and Berson [12]. The insulin response was calculated by subtracting the mean of baseline insulin levels from the values during stimulation by $20 \mathrm{mmol} / 1$ glucose or $10 \mathrm{mmol} / \mathrm{l}$ arginine.

Fasting plasma insulin levels were measured on blood samples drawn at 08.00 hours, $5 \mathrm{~h}$ after removing food from the rat cages.

Immunocytochemistry. After the pancreas perfusion, pancreases were fixed in Bouin's solution and embedded in paraffín. Two 5- $\mu \mathrm{m}$-thick serial sections of pancreas were stained, respectively, for insulin using anti-pork insulin guinea pig antibody (1:100, Miles-Yeda, Rehovot, Israel) and for GLUT 2 (1:1,000, number 1092) by indirect immunofluorescence methods described previously in detail [7]. To obtain percent of GLUT-2-positive beta cells more than 10 islets were randomly selected for the measurement of volume fraction of insulin-positive cells. Then the GLUT-2-positive cells were measured in the adjacent sections of the same islets. The volume fraction of GLUT-2-positive cells was divided by the volume fraction for insulin-positivity in each specimen to determine percent of GLUT-2 positive beta cells. For quantitation of the volume fraction of beta cells and non-beta cells serial sections were stained with insulin (1: 100, Miles-Yeda) or with a cocktail of antisera to glucagon $(1: 100,98 \mathrm{~J})$, somatostatin ( 1 : 100, Dako Corp., Carpinteria, Calif., USA) and pancreatic polypeptide $(1: 100$, Dako) by indirect immunofluorescence. The total area of insulin-positive cells (beta-cell volume fraction) or area inside the glucagon-somatostatin-pancreatic polypeptide-positive cells (non-beta-cell volume fraction) was measured and divided by total pancreas area. Morphometric analysis was performed by the method of Weibel [13] using a videometric image analyser system (American Innovision, San Diego, Calif., USA) attached to a Zeiss immunofluorescence microscope.

\section{Statistical analysis}

All values are expressed as mean \pm SEM. Statistical analysis was performed by a two-tailed unpaired Student's $t$-test (between two groups at 6 weeks only) or by a one-way analysis of variance at 12 and 18 weeks, at which times there were more than two groups.

\section{Results}

Effects of caloric restriction on plasma glucose and body weight. At 6 weeks of age the mean body weight of obese pre-diabetic rats was significantly greater $(p<0.01)$ than that of lean male ZDF littermates $(\mathrm{fa} /+)$ (Table 1$)$. The mean glucose level at 6 weeks of age did not differ significantly from normal. At 8 weeks of age all ZDF rats on an unrestricted diet had become hyperglycaemic, glycosuric and polyuric [mean plasma glucose level $15.2 \pm 2.6 \mathrm{mmol} /$ 1 vs $7.0 \pm 0.2 \mathrm{mmol} / 1$ in $\mathrm{ZDF}(\mathrm{fa} /+)$ ] (Fig. $1 \mathrm{~A})$. By contrast, none of the diet-matched obese pre-diabetic rats, in which the caloric intake was approximately half that of the unrestricted group, developed hyperglycaemia, glycosuria or polyuria during the 3 months of the study. For the first 10 weeks of dietmatching the weight in obese rats was the same as 

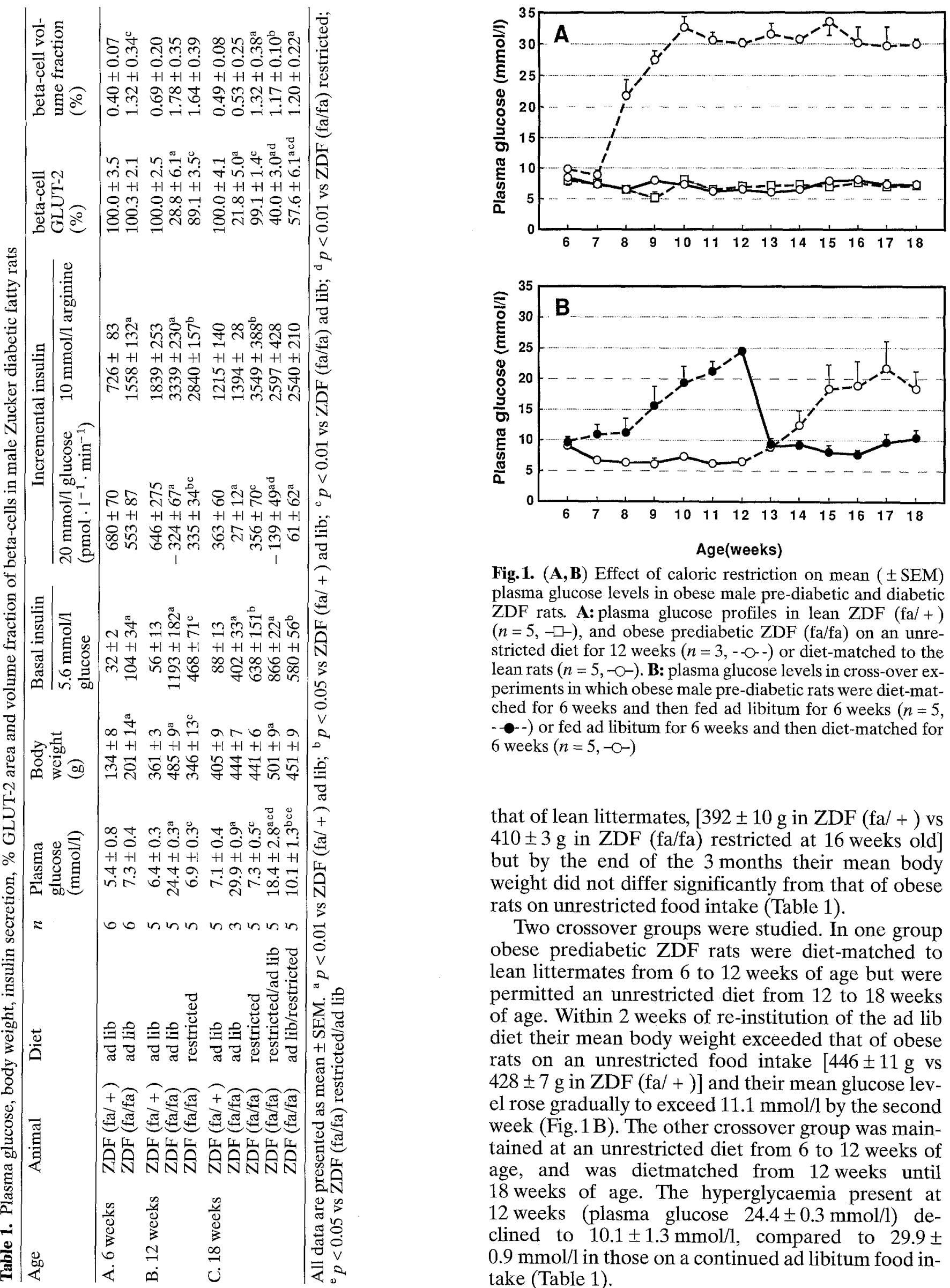

Fig.1. (A, B) Effect of caloric restriction on mean ( \pm SEM) plasma glucose levels in obese male pre-diabetic and diabetic ZDF rats. A: plasma glucose profiles in lean $\mathrm{ZDF}(\mathrm{fa} /+)$ $(n=5,-\square)$, and obese prediabetic ZDF (fa/fa) on an unrestricted diet for 12 weeks $(n=3,---)$ or diet-matched to the lean rats $(n=5,-\infty)$. B: plasma glucose levels in cross-over experiments in which obese male pre-diabetic rats were diet-matched for 6 weeks and then fed ad libitum for 6 weeks $(n=5$, - -) or fed ad libitum for 6 weeks and then diet-matched for 6 weeks $(n=5,-\infty-)$

that of lean littermates, [392 $\pm 10 \mathrm{~g}$ in ZDF (fa/ + ) vs $410 \pm 3 \mathrm{~g}$ in $\mathrm{ZDF}$ (fa/fa) restricted at 16 weeks old] but by the end of the 3 months their mean body weight did not differ significantly from that of obese rats on unrestricted food intake (Table 1).

Two crossover groups were studied. In one group obese prediabetic ZDF rats were diet-matched to lean littermates from 6 to 12 weeks of age but were permitted an unrestricted diet from 12 to 18 weeks of age. Within 2 weeks of re-institution of the ad lib diet their mean body weight exceeded that of obese rats on an unrestricted food intake $[446 \pm 11 \mathrm{~g}$ vs $428 \pm 7 \mathrm{~g}$ in ZDF ( $\mathrm{fa} /+)$ ] and their mean glucose level rose gradually to exceed $11.1 \mathrm{mmol} / \mathrm{l}$ by the second week (Fig. 1B). The other crossover group was maintained at an unrestricted diet from 6 to 12 weeks of age, and was dietmatched from 12 weeks until 18 weeks of age. The hyperglycaemia present at 12 weeks (plasma glucose $24.4 \pm 0.3 \mathrm{mmol} / \mathrm{l}$ ) declined to $10.1 \pm 1.3 \mathrm{mmol} / \mathrm{l}$, compared to $29.9 \pm$ $0.9 \mathrm{mmol} / 1$ in those on a continued ad libitum food intake (Table 1). 


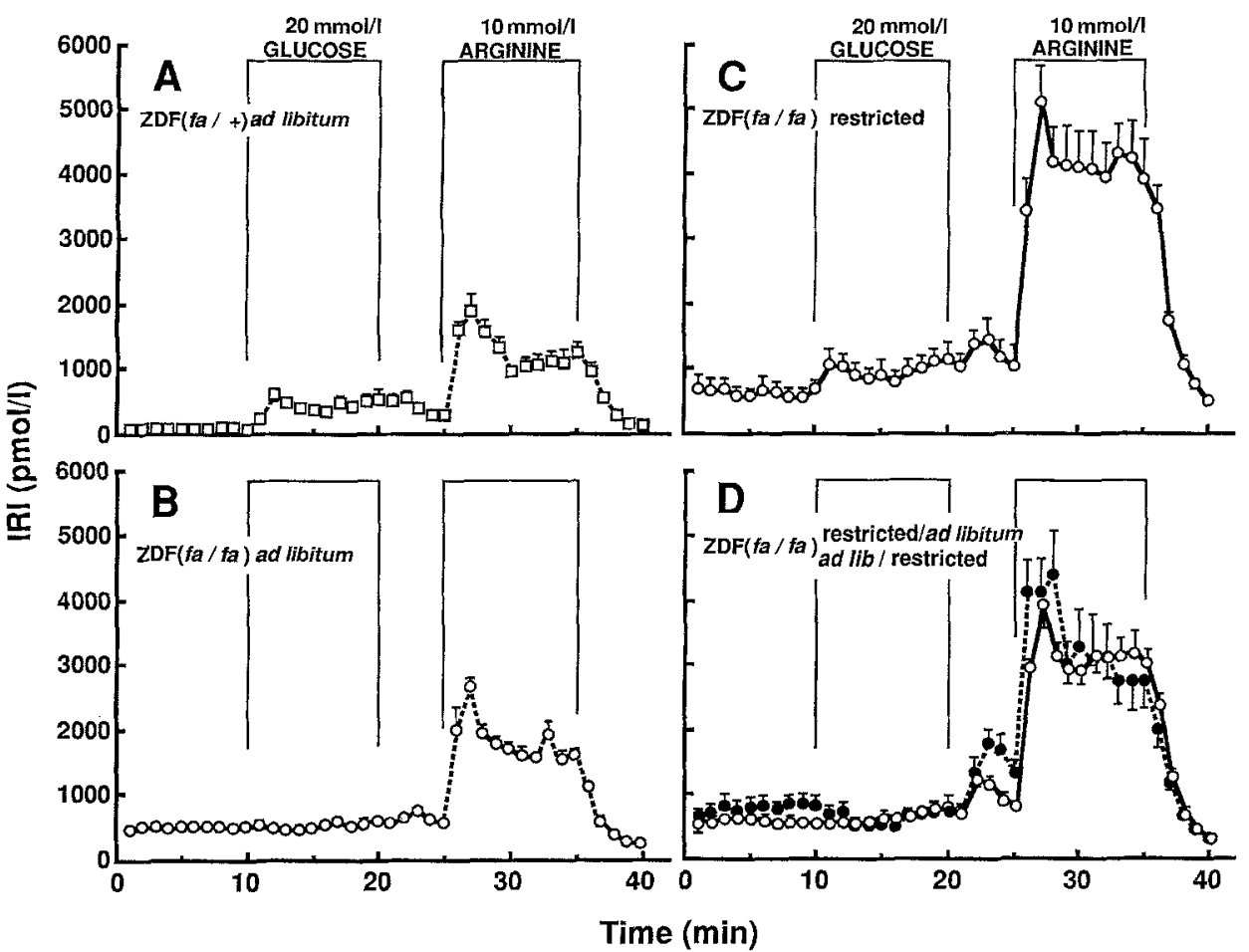

Fig. 2. (A-D) Mean ( \pm SEM) insulin levels in the effluent of isolated pancreata of 18 -week-old Zucker diabetic fatty rats perfused with $20 \mathrm{mmol} / \mathrm{l}$ glucose or $10 \mathrm{mmol} / \mathrm{l}$ arginine. A. Lean ZDF controls $(n=5,-\square)$, B. obese hyperglycaemic diabetics $(n=3,-\infty)$, C. obese normoglycaemic "diabetics" $(n=5,-0)$ D. obese diabetics in crossover studies $(n=5$ and 6 , respectively). Restricted/ad libitum (-०); ad libitum/restricted $(\bullet-)$. The perfusate included $5.6 \mathrm{mmol} / \mathrm{l}$ glucose and $5 \mathrm{mmol} / \mathrm{l}$ pyruvate, fumarate and glutamate throughout
Effects of caloric restriction on beta-cell function. At 6 weeks of age the basal insulin in the effluent of the isolated perfused pancreata of pre-diabetic obese ZDF rats was three times that of lean littermates $(104 \pm 34$ vs $33 \pm 2 \mathrm{pmol} / 1, \quad p<0.01)$, but the $553 \mathrm{pmol} / \mathrm{l}$ insulin response to $20 \mathrm{mmol} / \mathrm{l}$ glucose $\mathrm{did}$ not differ significantly from the $680 \mathrm{pmol} / 1$ response of the lean controls (Table 1). The response to $10 \mathrm{mmol} / \mathrm{l}$ arginine was more than twice as great as in the controls $(p<0.01)$ (Table 1$)$. Fasting plasma insulin levels averaged $76.6 \pm 19 \mu \mathrm{U} / \mathrm{ml}$ in pre-diabetic rats compared to $38.1 \pm 5 \pm 5.5$ in unrelated age-matched lean controls $(p=0.017)$.

At 12 weeks of age, after all rats on an unrestricted diet had become overtly diabetic (mean plasma glucose $24.4 \pm 0.3 \mathrm{mmol} / \mathrm{l}$ ), the incremental response to $20 \mathrm{mmol} / \mathrm{l}$ glucose was absent (Table 1 ). Their mean basal insulin level was over 10 times as high and the response to arginine twice as high as their values at 6 weeks of age. By contrast, in the diet-restricted normoglycaemic ZDF littermates $(6.9 \pm 0.3 \mathrm{mmol} / \mathrm{l})$ the incremental insulin response to $20 \mathrm{mmol} / 1$ glucose was present, although significantly reduced compared to lean controls $(p<0.05)$. The basal insulin was 4.5 -fold greater than at 6 weeks of age and the response to arginine was greatly exaggerated (Table 1 ). Their fasting plasma insulin levels averaged $65.7 \pm 18$ compared to $39 \pm 4.8 \mu \mathrm{U} / \mathrm{ml}$ in lean littermates (NS).

At 18 weeks of age in the severely hyperglycaemic obese male ZDF rats on an unrestricted diet (plasma glucose $29.9 \pm 0.9 \mathrm{mmol} / \mathrm{l}$ ) the incremental insulin response to $20 \mathrm{mmol} / 1$ glucose was absent and there was a small paradoxical rise in insulin when the glu- cose concentration was lowered to $5.6 \mathrm{mmol} / \mathrm{l}$ [14] (Table 1; Fig.2B). The basal insulin level averaged $402 \pm 33 \mathrm{pmol} / \mathrm{l}$, more than three times their level at 6 weeks of age and more than four times the level of lean littermates. The response to arginine was greatly exaggerated. By contrast, in the normoglycaemic diet-matched 18 -week-old male $\mathrm{ZDF}$ rats (plasma glucose $7.3 \pm 0.5 \mathrm{mmol} / 1$ ) the insulin response to $20 \mathrm{mmol} / \mathrm{l}$ glucose was the same as at 12 weeks. It was now the same as in the lean controls because their insulin response to glucose had declined by $44 \%$ from the value at 12 weeks of age (Table 1 ). The increased basal insulin secretion, the exaggerated arginine response and the paradoxical rise in insulin as glucose was reduced were still present (Fig. 2C).

The paradoxical rise in insulin observed by Malaisse et al. [14] in glucose-infused rats and attributed to glycogenolysis with glycolysis did not disappear in the diet-restricted rats (Fig. $2 \mathrm{C}$ ). In both crossover groups of obese ZDF rats (one group fed a restricted diet from 6 weeks to 12 weeks of age and ad libitum diet from 12 to 18 weeks of age; the other group on ad libitum diet from 6 to 12 weeks and on restricted diet from 12 to 18 weeks) the insulin response to glucose was absent or marginal (Fig. 2D). The high basal insulin secretion, the paradoxical rise in insulin as glucose was reduced and the exaggerated response to arginine persisted (Table 1).

Thus, responsiveness of beta cells to glucose appeared to be under the influence of the caloric intake or the metabolic milieu induced by the caloric excess or both, while the high basal insulin level and exag- 
gerated arginine-stimulated insulin response seemed to be independent of caloric intake. The modest reduction in hyperglycaemia to $10 \mathrm{mmol} / \mathrm{l}$ in the ad libitum/restricted group without improvement in insulin response to glucose probably reflects the effect of a reduction in carbohydrate intake upon the postprandial glucose level. The glucose level of $10.1 \pm 1.3 \mathrm{mmol} / \mathrm{l}$ was significantly greater than that of lean controls $(p<0.05)$.

Effect of caloric restriction on beta-cell volume fraction and percent of GLUT-2-positive beta-cell area. At 6 weeks of age the beta-cell volume fraction of the pre-diabetic ZDF (fa/fa) rats was more than three times that of lean littermates $(p<0.05)$ and at 12 weeks of age (approximately 4 weeks after the onset of hyperglycaemia) it was more than twice as great in the diabetic rats (Table 1). Thus, the onset of diabetes occurred at a time when the beta-cell volume fraction was far greater than that of lean littermates. However, by 18 weeks of age (about 10 weeks after the onset of hyperglycaemia) their beta-cell volume fraction had decreased to $24 \%$ of the measurement made 6 weeks earlier (Table 1 ). This profound loss of beta-cell volume fraction was completely prevented by caloric restriction, whether for a full 12 weeks or for only 6 weeks either before or after the onset of diabetes. In other words, the loss of beta-cell volume fraction occurred only in rats that received the ad libitum diet throughout their life. It is highly unlikely that the apparent loss of beta cells in these rats was the result of degranulation of beta cells rather than cellular depletion, in as much as crossover studies revealed no differences between rats on ad libitum/restricted and restricted/libitum regimes (Table 1 ). The dietary restriction did not prevent the gross distortion of beta-cell architecture (Fig. 3E).

Whereas the loss of beta-cell volume fraction occurred long after the onset of diabetes, the GLUT 2 loss in beta cells [6] and loss of GSIS [5] coincided with the appearance of hyperglycaemia [2]. In pre-diabetic ZDF (fa/fa) rats receiving an unrestricted diet, $100 \%$ of beta cells were GLUT-2-positive at 6 weeks of age (Fig. $3 \mathrm{~B}$ ), while less than $30 \%$ of beta cells were positive at 12 and 18 weeks of age (Fig. 3D and Table 1). In the pre-diabetic rats that had been dietrestricted from 6 to 18 weeks of age, $89 \%$ of betacells were GLUT-2-positive at 12 weeks of age and $99 \%$ were positive at 18 weeks of age (Table 1 ; Fig. $3 \mathrm{E}$ ). In the two crossover groups, (ad lib/restricted and restricted/ad lib), $58 \%$ and $40 \%$ of beta cells, respectively, were GLUT 2 positive (Table 1). It is possible that in the former group beta-cell GLUT-2 expression might have been increasing during the improvement in the metabolic milieu, while in the latter group a decrease in GLUT 2 was taking place as a consequence of the deteriorating metabolic state.
No differences in the volume fraction of non-beta cells were observed between any groups.

\section{Discussion}

Loss of beta-cell GLUT 2 and loss of GSIS appear to be invariant accompaniments of hyperglycaemia in obese diabetic male ZDF (fa/fa) rats [8] and all other models of rodent NIDDM thus far examined [15-17]. In addition, in two models of spontaneous NIDDM, obese $\mathrm{ZDF}$ rats [8] and $\mathrm{db} / \mathrm{db}$ mice [17], the volume of beta cells is reduced. In the present study we demonstrate that the loss of beta-cell GLUT 2 and of GSIS occur between 6 and 12 weeks of age, the period in which hyperglycaemia first appears. The betacell volume fraction, which at 6 weeks of age is 3.3 times that of lean littermates, is still 2.5 times that of the lean rats at 12 weeks, about 3-4 weeks after the onset of hyperglycaemia. Thus, the striking loss of beta-cell volume fraction observed at 18 weeks of age, about 10 weeks after the onset of hyperglycaemia, cannot be implicated in the pathogenesis of the metabolic derangement, but rather may be a late sequela. The mechanism of such a relationship is obscure. Surprisingly, despite the $75 \%$ reduction in beta cells, the high basal insulin secretion and the exaggerated response to arginine were not decreased.

By contrast, the loss of beta-cell GLUT 2 in rodent models of NIDDM is closely related both temporally and quantitatively to the hyperglycaemia and glucose-incompetence of beta cells $[8,18,19]$. Restriction of the caloric intake of 6-week-old pre-diabetic rats for 12 weeks prevented the loss of GSIS, the loss of beta-cell GLUT 2 and the loss of beta-cell volume. Beneficial effects of caloric restriction in $\mathrm{db} / \mathrm{db}$ mice have been previously reported [20]. However, whereas the loss of beta-cell volume was also completely prevented by 6 weeks of caloric restriction, whether before (between 6 and 12 weeks of age) or after the onset of diabetes (between 12 and 18 weeks of age), 6 weeks of caloric restriction failed to prevent the loss of beta-cell GLUT 2 or glucose incompetence; a full 12 weeks of caloric restriction were required to prevent loss of GLUT-2-positive beta cells and responsiveness to glucose. The gross distortion of islet architecture was not prevented by the full 12 weeks of diet-matching.

The results implicate loss of GLUT 2 and GSIS, rather than loss of beta cells, as possible factors in the pathogenesis of the initial hyperglycaemia of NIDDM in ZDF rats. They also suggest that all of these three lesions are secondary to the abnormal metabolic milieu or, less probably, to the dietary excess that produced it. This supports the conclusion of Thorens et al. [17] based on cross-transplantation of diabetic and non-diabetic islets that GLUT 2 loss is a consequence, rather than a cause, of the abnormal 


\section{Insulin}
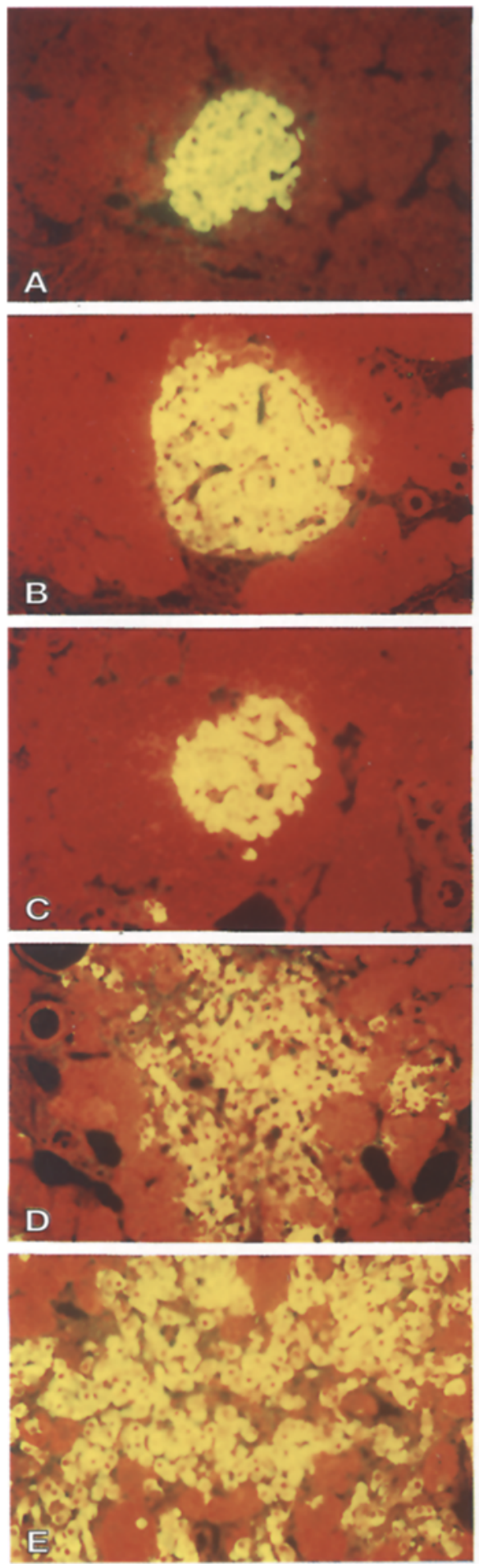

\section{GLUT-2}
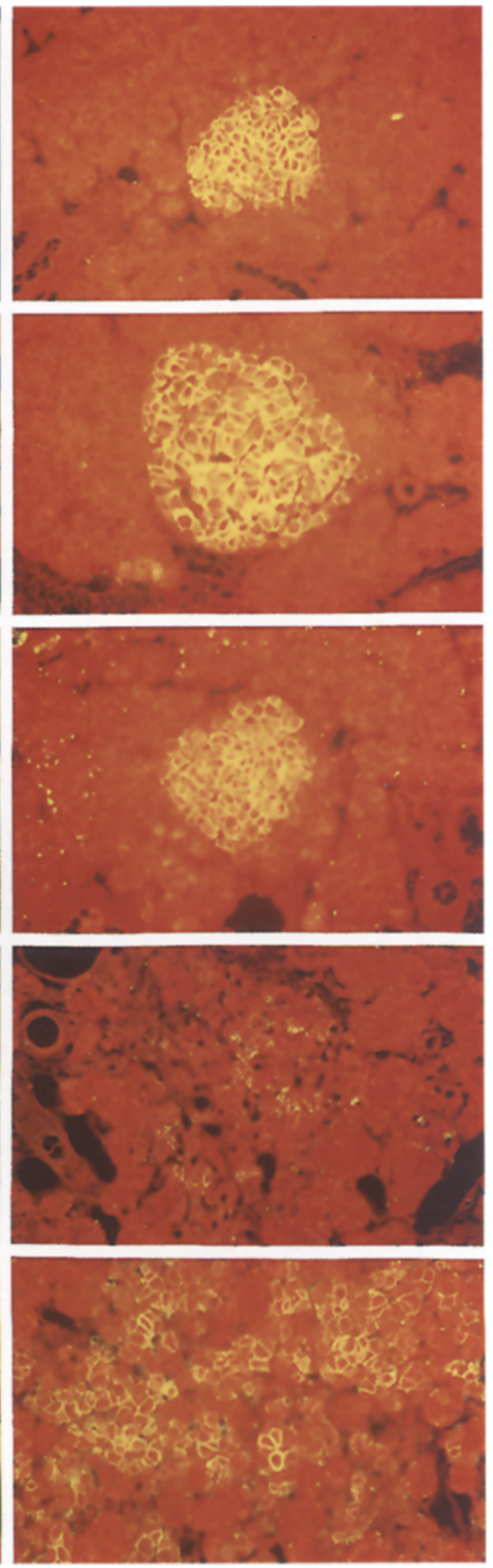

Fig. 3. (A-E) Immunostaining of pancreatic sections for insulin and GLUT 2 . A. 6-week-old lean $\mathrm{ZDF}(\mathrm{fa} /+$ ) on ad libitum diet B. 6-week-old obese pre-diabetic $\mathrm{ZDF}(\mathrm{fa} / \mathrm{fa})$ on ad libitum diet C. 18-week-old lean ZDF (fa/ + ) on ad libitum diet D. 18-week-old obese hyperglycaemic diabetic ZDF (fa/fa) on ad libitum diet E. 18-week-old obese normoglycaemic "diabetic" ZDF (fa/fa) on restricted diet. (Original magnification $\times 250$ ) metabolic state in NIDDM. The mechanism by which the metabolic abnormalities cause these beta-cell defects remains obscure, particularly in view of evidence that prevention of hyperglycaemia by means of acarbose fails to prevent loss of GLUT 2 [7]. If hyperglycaemia is exonerated as the metabolic cause of GLUT 2 loss, other metabolic derangements of NIDDM, such as abnormal lipid metabolism, might be suspect [21-24]. Indeed, recent work in our laboratory has demonstrated a dramatic increase in plasma non-esterified fatty acids and in islet triglyceride content in obese male pre-diabetic ZDF rats but not in the obese female non-diabetics [25]. Since both abnormalities are corrected by caloric restriction, it is entirely possible that the beta-cell changes in this form of NIDDM is secondary to lipotoxicity [25]. 
Increased basal insulin secretion and exaggerated arginine-stimulated insulin secretion, two other features of beta-cell dysfunction in obese ZDF rats with NIDDM, are also present in obese rats that do not develop diabetes $[8,17]$. In this study both abnormalities were present before the onset of diabetes and became more marked after the onset of diabetes. Neither were reversed or prevented by caloric restriction. Since beta-cell hyperresponsiveness has been reported in 5-day-old Zucker (fa/fa) rats [26], the possibility that these diet-independent components of the beta-cell phenotype in ZDF rats are genetically determined must be considered.

It should be pointed out that, in addition to change in caloric intake, the eating pattern of obese rats is altered by the $50 \%$ caloric restriction. On an unrestricted food intake they eat continuously throughout the day, whereas on the restricted diet the food is consumed within $3 \mathrm{~h}$.

Acknowledgements. This work was supported by National In stitutes of Health grants DK02700 and 1-P01-DK42582, Veterans Administration Research Support Grant 549-8000, Roussel-Uclaf Institute and the Greenwall Foundation. We wish to thank Ms. K. McCorkle, Ms. L. Kappler and Ms. T. Darwin for outstanding technical contributions and Ms. T. Autrey for excellent secretarial assistance. We thank Dr. C.Newgard for critically reading the manuscript.

\section{References}

1. Newburgh LH (1942) Control of hyperglycemia of obese diabetes by weight reduction. Ann Int Med 17: 935-942

2. Savage PJ, Bennion LJ, Flock EV et al. (1979) Diet-induced improvement of abnormalities in insulin and glucagon secretion and in insulin receptor binding in diabetes mellitus. J Clin Endocrinol Metab 48: 999-1007

3. Hidaka H, Nagulesparan M, Klimes I et al. (1982) Improvement of insulin secretion but not insulin resistance after short term control of plasma glucose in obese type II diabetics. J Clin Endocrinol Metab 54: 217-222

4. Peterson RG, Shaw WN, Neel M-A, Little LA, Eichberg J (1990) Zucker diabetic fatty rat as a model for non-insulin-dependent diabetes mellitus. ILAR News 32: 16-22

5. Pfeiffer MA, Halter JB, Porte D Jr (1981) Insulin secretion in diabetes mellitus. Am J Med 70: 579-588

6. Unger RH (1991) Diabetic hyperglycemia: link to impaired glucose transport in pancreatic $\beta$-cells. Science 251: 12001205

7. Orci L, Ravazzola M, Baetens D et al. (1990) Evidence that down-regulation of $\beta$-cell glucose transporters in non-insulin-dependent diabetes may be the cause of diabetic hyperglycemia. Proc Natl Acad Sci (USA) 87: 9953-9957

8. Johnson JH, Ogawa A, Chen L et al. (1990) Underexpression of $\beta$-cell high $\mathrm{K}_{\mathrm{m}}$ glucose transporters in noninsulindependent diabetes. Science 250: 546-549

9. Grodsky GM, Fanska RE (1975) The in vitro perfused pancreas. Methods Enzymol 39: 364-372
10. Hisatomi A, Maruyama H, Orci L, Vasko M, Unger RH (1985) Adrenergically mediated intrapancreatic control of the glucagon response to glucopenia in the isolated rat pancreas. J Clin Invest 75: 420-426

11. Herbert V, Lau KS, Gottlieb CW, Bleicher SJ (1965) Coated charcoal immunoassay of insulin. J Clin Endocrinol Metab 25: 1375-1384

12. Yalow RS, Berson SA (1960) Immunoassay of endogenous plasma insulin in man. J Clin Invest 39: 1157-1175

13. Weibel ER (1979) Practical methods for biological morphometry. In: Stereological Methods. Vol. 1. Academic Press, Inc., London pp. 101-161

14. Malaisse WJ, Magetto C, Leclercq-Meyer V, Sener A (1993) Interference of glycogenolysis with glycolysis in pancreatic islets from glucose-infused rats. J Clin Invest 91: 432-436

15. Thorens B, Weir GC, Leahy JL, Lodish HF, Bonner-Weir S (1990) Reduced expression of the liver/beta-cell glucose transporter isoform in glucose-insensitive pancreatic beta cells of diabetic rats. Proc Natl Acad Sci USA 87: 9953-9957

16. Ohneda M, Johnson JH, Inman LR et al. (1993) GLUT-2 expression and function in $\beta$-cells of $G K$ rats with NIDDM: dissociation between reductions in glucose transport and glucose-stimulated insulin secretion. Diabetes 42: 1065-1072

17. Thorens B, Wu YJ, Leahy JL, Weir GC (1992) The loss of GLUT2 expression by glucose-unresponsive $\beta$-cells of $\mathrm{db} /$ $\mathrm{db}$ mice is reversible and is induced by the diabetic environment. J Clin Invest 90: 77-85

18. Ogawa A, Johnson JH, Ohneda M et al. (1992) Roles of insulin resistance and $\beta$-cell dysfunction in dexamethasoneinduced diabetes. J Clin Invest 90: 497-504

19. Ohneda M, Johnson JH, Inman LR, Unger RH (1993) GLUT-2 function in glucose-unresponsive $\beta$-cells of dexamethasone-induced diabetes in rats. J Clin Invest 92: 1950-1956

20. Wyse B, Dulin W (1970) The influence of age and dietary conditions on diabetes in the $\mathrm{db}$ mouse. Diabetologia 6 : 268-273

21. Sako Y, Grill VE (1990) A 48-hour lipid infusion in the rat time-dependently inhibits glucose-induced insulin secretion and B-cell oxidation through a process likely coupled to fatty acid oxidation. Endocrinology 127: 1580-1589

22. Capito K, Hansen SE, Hedeskov CJ, Islin H, Thams $P$ (1992) Fat-induced changes in mouse pancreatic islet insulin secretion, insulin biosynthesis and glucose metabolism. Acta Diabetol 28: 193-198

23. Elks ML (1993) Chronic perifusion of rat islets with palmitate suppresses glucose-stimulated insulin release. Endocrinology 133: 208-214

24. Zhou Y-P, Grill VE (1994) Long-term exposure of rat pancreatic islets to fatty acids inhibits glucose-induced insulin secretion and biosynthesis through a glucose fatty acid cycle. J Clin Invest 93: 870-876

25. Lee Y, Hirose H, Ohneda M, Johnson JH, McGarry JD, Unger RH (1994) $\beta$-cell lipotoxicity in the pathogenesis of noninsulin-dependent diabetes mellitus (NIDDM) of obese rats: impairment in adipocyte- $\beta$-cell relationships. Proc Natl Acad Sci 91: 10878-10882

26. Atef N, Brulé C, Bihoreau M-T, Ktorza A, Picon L, Pénicaud L (1991) Enhanced insulin secretory response to acetylcholine by perifused pancreas of 5-day-old preobese Zucker rats. Endocrinology 129: 2219-2224 